Zeszyty Naukowe Szkoły Głównej Gospodarstwa Wiejskiego

Ekonomika i Organizacja Gospodarki Żywnościowej nr 118, 2017: 41-53

DOI 10.22630/EIOGZ.2017.118.15

Katarzyna Drabarczyk, Joanna Wrzesińska-Kowal

Wydział Nauk Ekonomicznych

Szkoła Główna Gospodarstwa Wiejskiego w Warszawie

Aleksandra Jakubiec

Instytut Rynków i Konkurencji

Szkoła Główna Handlowa w Warszawie

\title{
Spółdzielczość spożywców w Polsce w latach 2006-2014 na przykładzie wybranej spółdzielni
}

\section{Wstęp}

Spółdzielczość spożywców jest jedną z najstarszych branż spółdzielczości w Polsce. Badania naukowe dotyczące handlu wewnętrznego prowadzone są zazwyczaj na dużych sieciach handlowych lub skupiają się na indywidualnych przedsiębiorcach, a forma, jaką jest spółdzielczość spożywców, pozostaje pomijana. Za narodziny powszechnego ruchu spółdzielczego uważa się powstanie w 1844 roku Stowarzyszenia Sprawiedliwych Pionierów w Rochdale koło Manchesteru (ang. Rochdate Equitable Pioneers Society) w Wielkiej Brytanii [Pudełkiewicz 2009]. Spółdzielczość powstała z powodu narastającego problemu lichwy i spekulacji w handlu. Jest także elementem ekonomii społecznej, ponieważ jej celem bezpośrednim nie jest maksymalizacja zysku a zaspokajanie potrzeb członków spółdzielni. Nadrzędnym organem ruchu spółdzielczego w Polsce jest Krajowa Rada Spółdzielcza (KRS), która jest członkiem Międzynarodowego Związku Spółdzielczego (ang. ICA - International Co-operative Alliance) [Florek-Paszkowska 2016]. Rola spółdzielczości spożywców w Polsce jest niedoceniana. Spółdzielnie te dają pracę około 50 tys. osobom, przy czym utrzymują $\mathrm{w}$ długoletnim zatrudnieniu pracowników w wieku produkcyjnym niemobilnym, którzy mają małe szanse na zatrudnienie na rynku pracy.

W przypadku spółdzielczości spożywców każdy może zostać członkiem spółdzielni i być równoprawnym jej współwłaścicielem, a w związku z tym partycypować w zyskach, jak również decydować o kierunkach jej rozwoju. 


\section{Cel i metodyka badań}

Celem opracowania jest przedstawienie sytuacji spółdzielczości spożywców w Polsce na przykładzie wybranej spółdzielni zrzeszonej w Krajowym Związku Rewizyjnym Spółdzielni Spożywców „Społem”. Ze względu na poufność danych, w opracowaniu nie będzie podawana nazwa badanej spółdzielni. Dane pochodzą ze sprawozdań rady nadzorczej i zarządu spółdzielni. Mają one przybliżyć sytuację ekonomiczną w podmiotach gospodarczych działających jako spółdzielnie spożywców. Okres badawczy obejmuje lata 2006-2014. Wykorzystano miary dynamiki oraz struktury do przeprowadzenia analizy pionowej i poziomej poszczególnych składników sprawozdań.

\section{Zasady i rozwój spółdzielczości}

Spółdzielnia jest rodzajem podmiotu gospodarczego, którego działalność regulowana jest przepisami ustawy z 1982 roku Prawo spółdzielcze ${ }^{1}$ (ustawa ta była nowelizowana ponad 40-krotnie). Według tej ustawy, spółdzielnia jest dobrowolnym zrzeszeniem nieograniczonej liczby osób, o zmiennym składzie osobowym i zmiennym funduszu udziałowym, które w interesie swoich członków prowadzi wspólną działalność gospodarczą. Według ICA, spółdzielnia jest autonomicznym zrzeszeniem osób, które zjednoczyły się dobrowolnie w celu zaspokojenia swoich wspólnych aspiracji i potrzeb ekonomicznych, społecznych i kulturalnych poprzez współposiadane i demokratycznie kontrolowane przedsiębiorstwo [Piechowski 2013]. W 1996 roku ICA uchwaliła deklarację spółdzielczej tożsamości, w której zawarł siedem zasad spółdzielczości [Mering 2013]:

- dobrowolne i otwarte członkostwo,

- demokratyczna kontrola członkowska - każdy członek spółdzielni ma wyłącznie jeden głos,

- ekonomiczne uczestnictwo członków - nadwyżka finansowa może być przekazana członkom proporcjonalnie do ich transakcji ze spółdzielnią lub też na rozwój spółdzielni, a także na wspieranie innych dziedzin działalności zaaprobowanych przez członków,

- autonomia i niezależność - porozumienia zawierane z innymi organizacjami lub pozyskiwanie kapitału z obcych źródeł są dokonywane na warunkach, które zapewniają demokratyczną kontrolę wszystkim członkom,

- edukacja, szkolenie i informacje - każdy członek powinien mieć do nich dostęp, a zadaniem spółdzielców jest informowanie społeczeństwa o istocie spółdzielczości i korzyściach z nią związanych,

\footnotetext{
${ }^{1}$ Ustawa z dnia 16 września 1982 r. Prawo spółdzielcze (Dz.U. 1982, nr 30, poz. 210 z późn. zm.).
} 
- $\quad$ współpraca między spółdzielniami - spółdzielnie powinny umacniać ruch spółdzielczy poprzez współpracę zarówno na szczeblu lokalnym czy regionalnym, jak i krajowym oraz międzynarodowym,

- troska o społeczność lokalną - spółdzielnia poprzez stworzenie swojej polityki ma pracować na rzecz rozwoju lokalnego.

Wyróżnia się kilkanaście rodzajów spółdzielni. Spółdzielnie spożywców obok kilkunastu innych (np. banków spółdzielczych, spółdzielni socjalnych, spółdzielni rolniczych) są jednym z nich. Spółdzielnia spożywców stanowi formę współpracy ekonomicznej, ma w teorii zapewniać wysokiej jakości produkty i usługi po stosunkowo niskiej cenie, a jej głównym celem nie jest zysk pieniężny. W praktyce towary są wyceniane po cenach rynkowych.

Na ziemiach polskich umowną datą powstania spółdzielczości spożywców jest 1869 rok, kiedy powołano dwa pierwsze stowarzyszenia spożywców w Warszawie i Radomiu. Lokalne społeczności szybko zaczęły zakładać spółdzielnie po to, aby otrzymywać tanie towary o dobrej jakości. Spółdzielnie spożywców zdominowały szczególnie spółdzielczość zaboru rosyjskiego. Spopularyzowanie zagadnień spółdzielczości i intensywny rozwój samego ruchu spowodowały, że w 1906 roku początkowo tajne Towarzystwo Kooperatystów, czyli organizacja propagująca idee spółdzielczości, zaczęło wydawać tygodnik „Społem”. Sama nazwa pisma została wymyślona przez Stefana Żeromskiego, a hasło to przetrwało do dziś. Ruch spółdzielczości spożywców był rozproszony i wymagał szybkiego zjednoczenia, a także pomocy organizacyjnej, gospodarczej i finansowej, jak również centralnej organizacji zaopatrzenia i kontroli [Mroczek 2012]. W 1908 roku przy Towarzystwie Kooperatystów powołano Biuro Informacyjne składające się z działu gospodarczego i działu organizacyjno-propagandowego, które prowadziły działalność hurtowa, lustracyjną i społeczno-wychowawczą na rzecz spółdzielni spożywców. W 1911 roku zostało ono przekształcone w Warszawski Związek Stowarzyszeń Spożywców, który po kilkukrotnej zmianie nazwy, ostatecznie w 1992 roku stał się Krajowym Związkiem Rewizyjnym Spółdzielni Spożywców „Społem”2. Pod tą nazwą funkcjonuje do dziś. Jest to dobrowolna organizacja zrzeszająca spółdzielnie spożywców, która pełni funkcje rewizyjno-patronackie. Zajmuje się m.in. działalnością lustracyjną zrzeszonych spółdzielni oraz działalnością doradczą i szkoleniową integracją zrzeszonych spółdzielni, reprezentacją ich przed organami państwowymi czy samorządowymi, a także nawiązywaniem współpracy z ośrodkami naukowo-badawczymi [Cioch 2011].

Wraz z pojawieniem się na polskim rynku zagranicznych sieci handlowych zaostrzyła się konkurencja. Polskie spółdzielnie w nowej sytuacji rynkowej mu-

${ }^{2}$ KZRSS „Społem”, http://kzrss.spolem.org.pl/index.php/historia/kalendarium (dostęp: 21.01.2017). 
siały podjąć działalność dostosowawczą, która przypadła na lata 1990-1995. Podjęto działania mające na celu porządkowanie (racjonalizację) sieci własnych placówek oraz wzmacnianie ich pozycji na rynku. Spółdzielczość spożywców rozwinęła sieć rozpoznawalnych sklepów „Lux” oraz dyskontowych [Chyra-Rolicz 2006]. W 2016 roku czynnie funkcjonowało 310 spółdzielni spożywców, ale nie wszystkie były zrzeszone w KZRSS „Społem”. Spółdzielnie spożywców zajmują się nie tylko handlem detalicznym i hurtowym. W 2014 roku posiadały one ok. 4 tys. sklepów detalicznych o łącznej powierzchni użytkowej ponad 700 tys. $\mathrm{m}^{2}$, własne magazyny, ponad 200 piekarni, 230 lokali gastronomicznych, kilka masarni oraz własne hotele. W ostatnich latach sieć „Społem” poszerzała swoją ofertę o produkty marki własnej. Pod koniec 2014 roku w ofercie było 180 takich produktów. Rok później liczba ta wzrosła do ponad 200 i obejmowała już nie tylko produkty spożywcze, ale także produkty AGD, chemiczne i kosmetyczne. Produkty marek własnych są zazwyczaj tańsze, ale marże są na nich wyższe. Sprzedaż pod znaną już nazwą „Społem” pozwala na pominięcie kosztów marketingu.

Badana spółdzielnia jest jedną z wielu funkcjonujących w Polsce, dlatego też wnioski z prowadzonych badań nie moga być przekładane na cały sektor spółdzielczości spożywców.

\section{Spółdzielczość spożywców w badaniach}

Działalność spółdzielni spożywców jest analizowana z perspektywy różnych dyscyplin naukowych, w tym ekonomii, finansów i zarządzania. W niektórych krajach nazywane są one kooperatywami handlowymi lub spółdzielniami konsumenckimi. W publikacjach krajowych zagadnienie spółdzielczości spożywców jest na ogół traktowane marginalnie.

Sytuację spółdzielni działających w poprzednim systemie gospodarczym w Polsce badali m.in. Niestrój i Szumilak [1990], którzy analizowali warunki samofinansowania w 4 krakowskich spółdzielniach spożywców w latach 1982-1987. Odnotowali bardzo duże wartości wskaźników dynamiki sprzedaży. Przyrost cen wyraźnie wyprzedzał ujęty wartościowo przyrost obrotów, a więc przyrost efektu rzeczowego albo w ogóle nie wystapił, albo był niewielki. W wyniku urzędowo ustalanych marż na towary spółdzielnie charakteryzowały się małą dynamiką dochodu.

Nowacka [1999] badała podstawowe wskaźniki rentowności w 210 spółdzielniach spożywców „Społem” w latach 1995-1997. Wykazała wzrost poziomu rentowności obrotu brutto i netto w tym okresie, ale mimo tego wskaźniki kształtowały się na niskim poziomie, nie zapewniając badanym spółdzielniom 
możliwości rozwojowych. Rentowność majątku trwałego, rentowność majątku obrotowego i rentowność kapitału własnego, które w 1995 roku były ujemne, w latach 1996-1997 osiąnęły wartości dodatnie, jednak na bardzo niskim poziomie.

Wieszałka [2003] analizował infrastrukturę sieci „Społem” w 1999 roku na przypadku 14 wybranych spółdzielni (dużych, małych i średnich) zlokalizowanych w miastach w województwie śląskim o zaludnieniu powyżej 150 tys. mieszkańców. Z badań bezpośrednich, obejmujących m.in. szerokość i głębokość asortymentu, lokalizację, poziom innowacyjności i wyposażenia technicznego, wynikała potrzeba repozycjonowania znacznej części punktów sprzedaży detalicznej, będących własnością badanych spółdzielni.

Parszewski i Jakubiak [2011] rozpatrywali strategię zarządzania PSS „Społem” w Ostrołęce. Zwrócili uwagę na zagrożenia, jakie niosła konkurencja na rynku lokalnym, w szczególności ze strony największych sieci handlowych, takich jak: Lidl, Biedronka, Zielony Market, PoloMarket, E.Leclerc czy Stokrotka. Zaznaczyli również, że nakłady na modernizację sklepów powodują jedynie utrzymanie dotychczasowego poziomu sprzedaży, a nie rekompensują strat wynikających ze wzrostu kosztów utrzymania placówek w obiektach dzierżawionych.

Jeśli chodzi o zagraniczną literaturę, to przykładowo Katchova i Woods [2011] badali 350 spółdzielni działających na terenie USA w 2010 roku. Okazało się, że w porównaniu do innych sklepów spożywczych spółdzielnie miały wyraźne korzyści ze współpracy z lokalnymi producentami żywności. Produkty lokalne przynosiły średnio prawie 22\% wartości brutto rocznej sprzedaży. Dzięki takiej współpracy okoliczni producenci zapewniali sobie rynek zbytu, a spółdzielnie przyciaggały coraz więcej klientów.

W wielu krajach pozycja spółdzieli spożywców na rynku jest znaczna. Przykładowo we Włoszech spółdzielnia Coop Italian Food ${ }^{3}$ w 2014 roku miała 18,5\% udziału w sprzedaży, wyprzedzając takie sieci jak Carrefour (7,4\%) czy Auchan (9\%). Dzięki 1100 sklepom i 100 hipermarketom zlokalizowanym w 893 miastach osiagnęła obrót równy 2,7 mld euro.

W USA spółdzielnia spożywców Puget Consumers Cooperative (PCC) Natural Markets, która działa od 1954 roku, uzyskała w 2015 roku przychody ze sprzedaży na poziomie ponad $250 \mathrm{mln}$ USD, a zysk netto osiagnął ok. $5,5 \mathrm{mln}$ USD. Spółdzielnia zatrudniała prawie 1400 osób, a także aktywnie realizowała misję społeczną, przekazując 55 t produktów spożywczych bankom żywności ${ }^{4}$.

W Finlandii pod koniec 2015 roku działały następujące sieci spożywców: Prisma (64 sklepy), S-Market (436 sklepów), Sale i Alepa (łącznie 384 sklepy).

${ }^{3}$ Coop Italian Food, http://www.e-coop.it/CoopRepository/COOP/coop-italian-food (dostęp: 23.01.2017).

${ }^{4} \mathrm{PCC}$, http://www.pccnaturalmarkets.com (dostęp: 23.01.2017). 
Spółdzielnie te, obok innych, wchodzą w skład Suomen Osuuskauppojen Keskuskunta (określanej jako S-gruppen), czyli krajowej organizacji spółdzielczej. W 2015 roku zatrudniała ona 37758 osób, wartość sprzedaży detalicznej wyniosła 10,8 mld euro, a udział w rynku stanowił ponad $45 \%$.

\section{Charakterystyka wybranej spółdzielni}

Badana spółdzielnia działa na terenie Warszawy od lat 30. XX wieku. Prowadzi działalność handlową oraz usługową w zakresie wynajmu wolnych powierzchni użytkowych i doładowań telefonów. Od 2011 roku prowadzi także usługę pośrednictwa finansowego polegającą na możliwości opłacania w kasie sklepów rachunków za media.

Liczba zrzeszonych członków w latach 2006-2014 zmniejszyła się z 558 do 338 osób, czyli prawie o 40\%. Wartość jednego udziału w latach 2006-2007 wynosiła $200 \mathrm{zl}$, w kolejnych latach $400 \mathrm{zł}$.

W ciagu badanego okresu liczba placówek handlowych zmieniała się z roku na rok. Likwidacja sklepów w poszczególnych latach nie była spowodowana wyłącznie brakiem rokowań na zwiększenie sprzedaży i poprawę sytuacji ekonomicznej, ale też takimi czynnikami, jak: zalanie sklepów w wyniku powodzi, nie przedłużenie umowy najmu przez właściciela lokalu i podwyżka opłat za wynajem, rozpoczęcie procesu inwestycyjnego, sprzedaż budynku lub wydzierżawienie go podmiotom obcym.

W latach 2006-2014 spółdzielnia podwoiła (z 5 na 10) liczbę placówek własnych (rys. 1), co w perspektywie dalszej działalności pozwoliło uniknąć problemów związanych z obiektami wynajmowanymi (np. brak przedłużenia umowy może skutkować koniecznością likwidacji sklepu, w konsekwencji zmniejszeniem ogólnego obrotu i zysku spółdzielni). Jednostkowa powierzchnia placówek własnych wahała się od 284 do $518 \mathrm{~m}^{2}$. W placówkach obcych wynosiła od 619 do $724 \mathrm{~m}^{2}$ i była większa średnio o $69 \%$ od powierzchni placówek własnych. W obiektach zarówno własnych, jak i obcych spółdzielnia wynajmowała powierzchnię innym podmiotom. Średnia powierzchnia sprzedaży w badanych latach w placówkach własnych stanowiła $379 \mathrm{~m}^{2}$, w placówkach obcych $613 \mathrm{~m}^{2}$.

Liczba zatrudnionych w spółdzielni wahała się od 469 do 554 osób. Przeciętnie poza rynkiem detalicznym (w administracji, działalności pomocniczej) pracowało 13\% ogółu zatrudnionych. Liczba pracujących w sklepach detalicznych (kadra kierownicza, sprzedawcy, obsługa komputerów, pracownicy gospodarczy) przypadająca na jeden sklep wynosiła przeciętnie od 18 do 21 osób

${ }^{5}$ S-kanava.fi, https://www.s-kanava.fi/web/s/en/s-ryhma-lukuina (dostęp: 23.01.2017). 


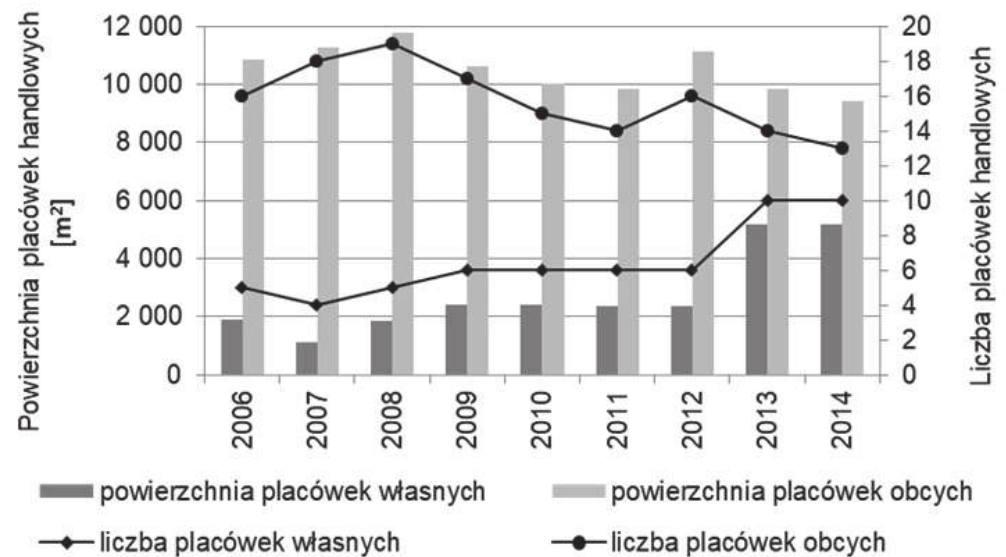

\section{Rysunek 1}

Liczba placówek handlowych spółdzielni i ich powierzchnia sprzedaży w latach 2006-2014 Źródło: Opracowanie własne.

w analizowanym okresie. Wielkość zatrudnienia w spółdzielni kształtowana była na podstawie rentowności placówek, organizacji pracy, dostosowywania form sprzedaży do potrzeb klienta, liczby stoisk serwisowych oraz wymogów formalnoprawnych dotyczących czasu pracy.

Spółdzielnia dbała o kapital ludzki, szkoląc swoich pracowników. W 2011 roku przeszkolono ich stosunkowo najwięcej (83\% ogółu). Największe koszy $\mathrm{z}$ tego tytułu poniesiono w 2010 roku (ponad 178 tys. zł). Przeciętny koszt przeszkolenia jednego pracownika wahał się od 357 zł (2007 r.) do 908 zł (2009 r.). Poza głównymi i koniecznymi tematami szkoleń, takimi jak BHP czy szkolenia dla pracowników administracji na temat bieżących zmian w prawie (np. zagadnienia podatkowe, kadrowo-płacowe, dotyczące czasu pracy, ochrony danych osobowych, sporządzania bilansu) organizowano szkolenia z zakresu: technik sprzedaży/marketingowych, budowania i motywowania zespołu, komunikacji w zespole, zarządzania zespołem czy podstawowych zasad ekspozycji towarowej i controllingu (rys. 2).

Przeciętne nominalne wynagrodzenie brutto w spółdzielni wzrosło w latach 2006-2014 o 53\% (z 2255 do 3453 zł) W całym badanym okresie przewyższało ono średnią płacę w polskiej gospodarce. W odniesieniu do średniej płacy w handlu (w sekcji G) było podobne do 2010 roku, po czym tendencja ta odwróciła się. Wyłącznie w jednym roku (2014 r.) średnia płaca w badanej spółdzielni spadła w stosunku do roku poprzedniego. Było to wynikiem wprowadzenia grafików czasu pracy, co usprawniło organizację pracy i ograniczyło wielkość nadgodzin, a w efekcie skutkowało spadkiem wynagrodzeń (rys. 3). Badana spółdzielnia stosowała czasowo-premiowo-prowizyjny system wynagradzania. 


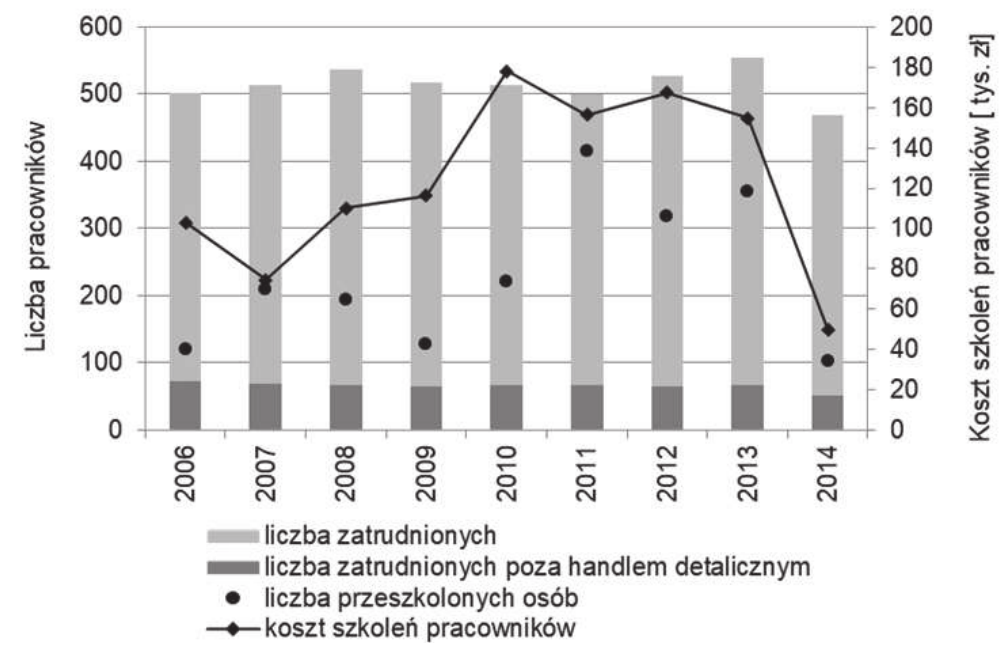

Rysunek 2

Liczba zatrudnionych i przeszkolonych osób w spółdzielni oraz koszty szkoleń w latach 2006$-2014$

Źródło: Opracowanie własne.

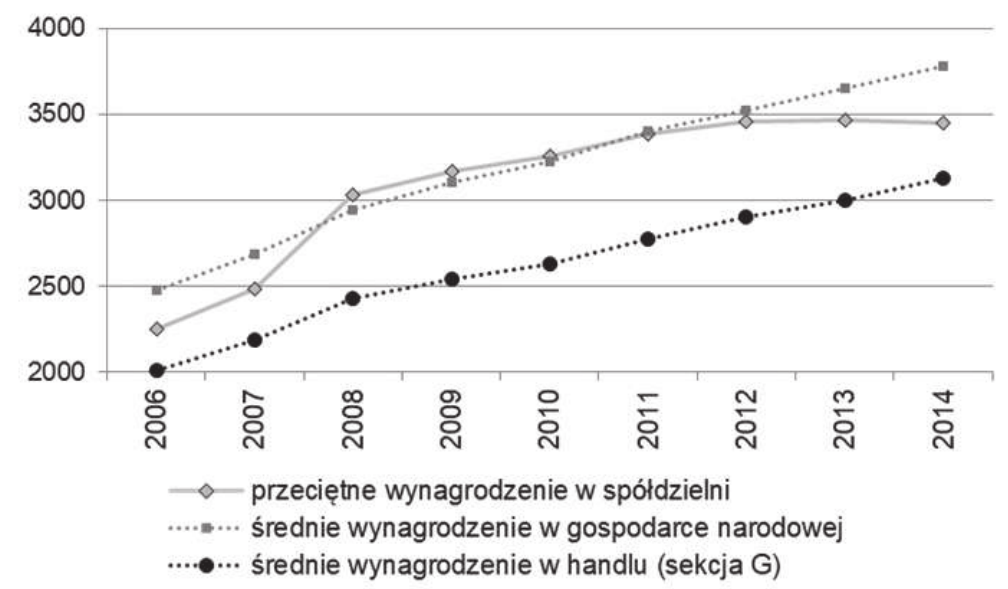

\section{Rysunek 3}

Przeciętne nominalne wynagrodzenie brutto w spółdzielni, gospodarce narodowej i handlu (sekcja G) w latach 2006-2014 [zł]

Źródło: Opracowanie własne.

Jeśli chodzi o sytuację ekonomiczno-finansową spółdzielni, to w całym okresie osiagała ona dodatni wynik wyłącznie na działalności finansowej (rys. 4). Przychody z działalności finansowej pochodziły głównie z odsetek od środków na rachunkach bankowych. Wynik na podstawowej działalności operacyjnej był ujemny w latach 2013-2014, co ostatecznie wpłynęło na stratę na 


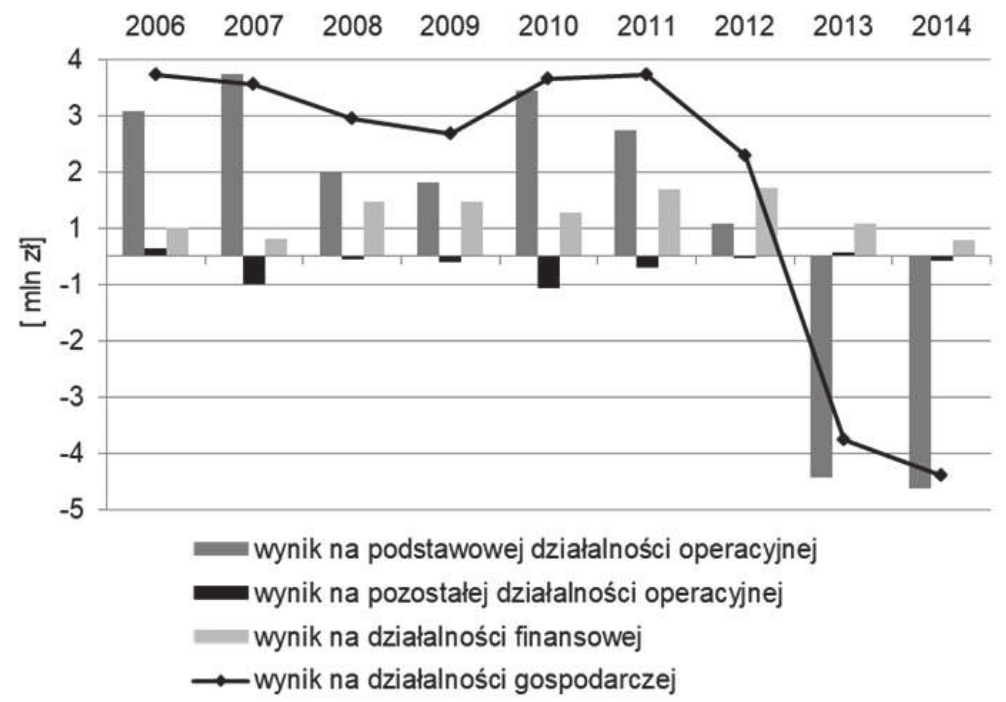

Rysunek 4

Wynik finansowy na działalności gospodarczej spółdzielni i jego składowe w latach 2016-2014 [mln zł]

Źródło: Opracowanie własne.

działalności gospodarczej. Ogółem na działalności gospodarczej w 2013 roku spółdzielnia osiagnęła stratę w wysokości 3,26 mln zł, na co decydujący wpływ miał wzrost koszów handlowych (o ponad 5,2 mln zł) w podstawowej działalności operacyjnej, związany z uruchomieniem 4 nowych placówek oraz likwidacją 2 innych, w których nastapiło zmniejszenie sprzedaży. Dodatkowo zmniejszyły się wpływy z promocji - marketingu w imieniu kontrahentów (o ponad 1,2 mln zł) i z działalności finansowej (o ponad 600 tys. zł). W 2014 roku strata na działalności gospodarczej sięgała prawie 3,9 mln zł, głównie w wyniku zmniejszenia wartości sprzedaży w placówkach przy relatywnie mniejszej dynamice spadku kosztów sprzedaży. Od 2012 roku koszty handlowe zaczęły przewyższać wypracowaną marżę. Należy zaznaczyć, że skutki spadku obrotu odczuwalne są natychmiast, a szybkie zmniejszenie kosztów, mimo podjętych działań, nie jest możliwe.

W celu poprawy wyniku finansowego na prowadzonej działalności spółdzielnia określiła następujące podstawowe kierunki działania na kolejne lata:

- poprawa rentowności sprzedaży przez: polepszenie warunków zakupowych, uatrakcyjnienie oferty handlowej, ograniczanie kosztów,

- zmiana organizacji pracy w sklepach,

- wdrożenie nowego systemu informatycznego do zarządzania sprzedażą w sklepach i centrali, 
- rozwój sieci poprzez pozyskanie nowych sklepów,

- przyłączenie się do grupy zakupowej w celu osiągnięcia poprawy warunków handlowych.

Rysunek 5 prezentuje zmiany w strukturze bilansu spółdzielni w latach 2006-2014. W 2014 roku suma bilansowa wynosiła prawie $57 \mathrm{mln}$ zł i była wyższa o ponad $12 \mathrm{mln}(27 \%)$ w stosunku do 2006 roku. Majątek trwały w całym okresie zwiększył się o 12,5 mln zł, głównie za sprawą kategorii środki trwałe, co miało związek z podwojeniem się liczby placówek własnych. Istotny wzrost w kategorii aktywa obrotowe nastapił w latach 2006-2011. Spowodowane było to zwiększeniem się środków pieniężnych z niespełna $15 \mathrm{mln}$ do $26,4 \mathrm{mln}$ zł. Suma kapitałów własnych wzrosła w badanych latach o blisko $10 \mathrm{mln}$ zł. Wśród kapitałów własnych znacząco powiększył się kapitał zapasowy (z ok. 12,5 mln zł w 2006 r. do ponad $42 \mathrm{mln}$ zł w 2014 r.) Oznaczało to, że spółdzielnia była przygotowana do pokrycia ewentualnych strat w kolejnych latach działania. Kapitały obce w 2014 roku wynosiły $16,9 \mathrm{mln}$ zł i były o $2,3 \mathrm{mln}$ zł większe niż w 2006 roku. Zwiększyły się zobowiązania długoterminowe spółdzielni (pobrane kaucje od najemców) i fundusze specjalne.

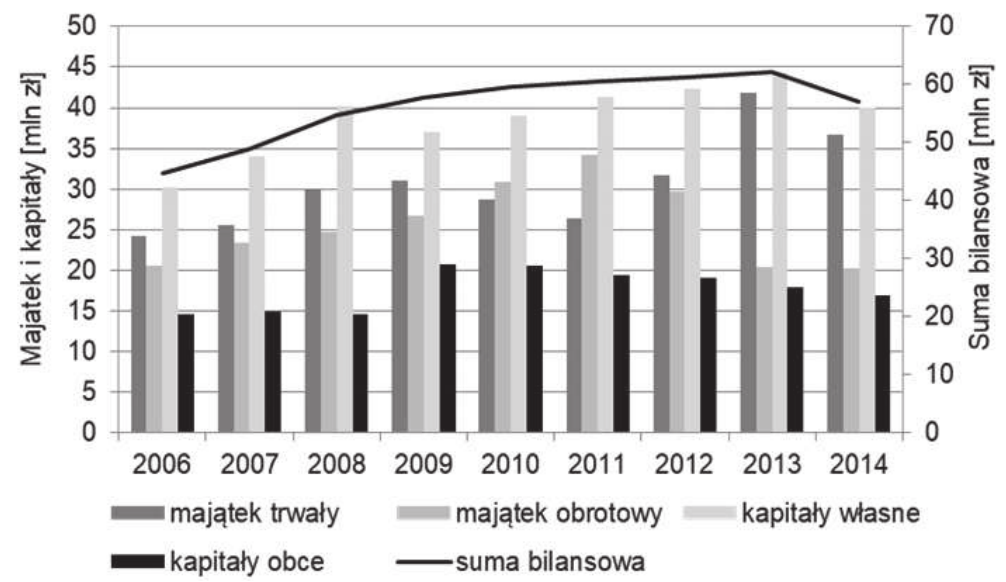

Rysunek 5

Suma bilansowa i struktura bilansu spółdzielni w latach 2006-2014

Źródło: Opracowanie własne.

\section{Podsumowanie}

Spółdzielczość spożywców w Polsce nie jest tak znacząca pod względem gospodarczym i równie rozwinięta jak w innych krajach, przykładowo we Włoszech, Finlandii czy USA. 
Na podstawie badań własnych dotyczących jednej z wielu spółdzielni zrzeszonych w KZRSS „Społem” stwierdzono jej rozwój pod względem ekonomiczno-finansowym w latach 2006-2014. Zwiększyła się liczba sklepów mieszczących się w placówkach własnych przy ich spadku w placówkach obcych. Nastapił również wzrost przeciętnej powierzchni sklepów w obydwu rodzajach placówek. Liczba zatrudnionych w 2014 roku była jednak o ponad 6\% mniejsza w stosunku do 2006 roku. W efekcie redukcji zatrudnienia i zwiększenia się liczby sklepów, zmniejszyła się przeciętna liczba osób pracujących w sprzedaży detalicznej w przeliczeniu na 1 sklep. Spółdzielnia inwestowała w kapitał ludzki. Łącznie w badanych latach poniosła koszty szkoleń pracowników sięgające ponad 1,1 mln zł. Przeciętne nominalne wynagrodzenie w tym czasie wzrosło o 53\%. Mimo iż w latach 2013-2014 spółdzielnia wykazała stratę na działalności gospodarczej, nie stanowi to powodu do niepokoju, ponieważ podjęte działania w zakresie zmniejszenia kosztów nie dają zazwyczaj natychmiastowych efektów. Ponadto w tych latach suma kapitału zapasowego była kilkukrotnie większa niż poniesiona strata, a więc kontynuacja działania nie była zagrożona. Niepokojący jest jednak sukcesywny spadek liczby członków analizowanej spółdzielni.

Co do perspektyw rozwoju spółdzielczości spożywców w Polsce, to należy stwierdzić, że niestety wiele spółdzielni w przypadku małej rentowności nie poszukuje sposobów na wzmocnienie swojej pozycji poprzez kooperację lub fuzję, ale decyduje się na likwidację. Dochodzi wówczas do przejęcia dorobku wielu pokoleń spółdzielców przez konkurencyjne podmioty.

Mocną stroną spółdzielni spożywców w Polsce, w porównaniu do zagranicznych sieci handlowych dysponujących dużym kapitałem, jest dobra znajomość rynku lokalnego, wieloletnie doświadczenie w branży oraz lojalni klienci.

\section{Literatura}

CHYRA-ROLICZ Z., 2006: Polska spółdzielczość wobec problemów globalizacji: tezy do dyskusji, Nierówności Społeczne a Wzrost Gospodarczy. Problemy Globalizacji i Regionalizacji 9(2), 29-39.

CIOCH H., 2011: Prawo spółdzielcze, Wydawnictwo Wolters Kluwer, Warszawa.

FLOREK-PASZKOWSKA A., 2016: Współczesne spółdzielnie spożywców w Polsce na tle historycznym, Zagadnienia Doradztwa Rolniczego 3(85), 61-75.

KATCHOVA A.L., WOODS T.A., 2011: The effectiveness of local food marketing strategies of food cooperatives, Agricultural and Applied Economics Association's. Annual Meeting, July 24-26, Pittsburgh, Pennsylvania.

MERING T., 2013: Spółdzielczość a polityka Unii Europejskiej w okresie kryzysu finansowego i gospodarczego, Problemy Polityki Społecznej. Studia i Dyskusje 20(1), 67-87. 
MROCZEK J., 2012: Poczatki rozwoju spółdzielczości w Polsce, Przegląd Prawniczy, Ekonomiczny i Społeczny 1, 29-40.

NIESTRÓJ R., SZUMILAK J., 1990: Warunki samofinansowania przedsiębiorstw handlowych (na przykładzie krakowskich spółdzielni spożywców), Zeszyty Naukowe Akademii Ekonomicznej w Krakowie 333, 53-65.

NOWACKA B., 1999: Rentowność Spółdzielni Spożywców Społem w latach 1995-1997, Handel Wewnętrzny 45(3), 46-52.

PARSZEWSKI K.K., JAKUBIAK K., 2011: Strategia zarzqdzania spótdzielniq na przykładzie ,, Społem” PSS w Ostrołęce, Zeszyty Naukowe Ostrołęckiego Towarzystwa Naukowego 25, 107-115.

PIECHOWSKI A., 2013: Wartości i zasady spółdzielcze a społeczeństwo obywatelskie i gospodarka społeczna, Ekonomia Społeczna 1, 34-47.

PUDEŁKIEWICZ E., 2009: Spółdzielcze formy gospodarowania w Polsce i w innych krajach Unii Europejskiej, Zeszyty Naukowe SGGW, Polityki Europejskie, Finanse i Marketing 2(51), 259-295.

WIESZAŁKA O., 2003: Infrastruktura sieci detalicznej dawnych liderów rynku detalicznego (wyniki badań w wybranych spółdzielniach ,,Społem”), Handel Wewnętrzny 6, 47-54.

Ustawa z dnia 16 września 1982 r. Prawo spółdzielcze. Dz.U. 1982 nr 30, poz. 210.

\section{Abstrakt}

Celem opracowania jest przedstawienie spółdzielczości spożywców w Polsce w latach 2006-2014 na przykładzie wybranej spółdzielni zrzeszonej w Krajowym Związku Rewizyjnym Spółdzielni Spożywców „Społem”. Dokonano charakterystyki wybranej spółdzielni pod kątem liczby placówek, ich powierzchni, liczby zatrudnionych i wysokości płac. Zaprezentowano również finansowe wyniki działalności gospodarczej, sumę i strukturę bilansu oraz mocne strony dalszego rozwoju. Stwierdzono rozwój badanej spółdzielni pod względem ekonomiczno-finansowym.

Słowa kluczowe: spółdzielczość spożywców, handel detaliczny, spółdzielnie

\section{Consumers cooperatives in Poland in the years 2006-2014: the case study of the selected cooperative}

\section{Abstract}

The aim of this paper is to present the consumers cooperatives in Poland in the years 2006-2014 on the example of the selected cooperative being a member of the National Supervision Union of Spolem Consumer Cooperatives. To characterise the chosen cooperative, the number and area size of their business 
establishments were presented, as well as the number of employees and their wages. It was followed by the financial results of the business activity, the balance sheet and its components as well as the strengths leading to further development. Taking into account economic and financial performamce of the cooperative, it was developing in the analyzed period.

Key words: consumers cooperatives, retail trade, cooperatives 